\title{
BIODEGRADASI REMAZOL BRILIANT BLUE DALAM SISTEM BIOFILTRASI VERTIKAL DENGAN INOKULUM BAKTERI DARI SEDIMEN SUNGAI MATI IMAM BONJOL DENPASAR
}

\author{
Luh Putri Kriswidatari ${ }^{\left.{ }^{*}\right)}$, I W Budiarsa Suyasa ${ }^{1)}$, dan I Made Siaka ${ }^{1)}$ \\ 1)Jurusan Kimia Fakultas MIPA Universitas Udayana \\ *Email : putrikris88@gmail.com
}

\begin{abstract}
The biodegradation research of Remazol Brilliant Blue (RBB) has been done in vertical biofiltration systems with bacterial inoculum that had seed from soil Mati River Imam Bonjol Denpasar. This aims of research are to obtain the best active suspension grown from soil samples of Mati river sediment and to determine the magnitude of the effectiveness and capacity of biosystem. The artificial waste water of RBB has made with a concentration of $200 \mathrm{mg} / \mathrm{L}$. In the first phase, the best active suspension is obtained by determining the value of VSS (Volatile Suspended Solid ) is the highest as a source of inoculum of bacteria capable of degrading RBB. While the second phase, the effectiveness and capacity of biosystem is obtained by determining the levels of waste of artificial RBB vertical biofiltration system (biosystem). Biofilm has made with attached bacteria consortium in volcanic rock for 7 days. RBB subsequently incoporated into it to determine the concentration of it and to determine the effectiveness and capacity and identified the bacteria contained in biosystem. The results showed the best sludge active from soil sediments of the Mati River Imam Bonjol Gang Keladian with a value of Volatile Suspended Solid (VSS) highest of $17200 \mathrm{mg} / \mathrm{L}$ when the sreeding time of 48 hours. The results of processing using biosystem known to decreased when the processing time from 6 hours up to 114 hours, from concentration of $200 \mathrm{mg} / \mathrm{L}$ to $19.6211 \mathrm{mg} / \mathrm{L}$. Then the prosses has increased again into $19.8209 \mathrm{mg} / \mathrm{L}$ at the time to 120 hours. The highest effectivity of biosystem to degrading remazol brilliant blue of $90.19 \%$ for 114 hours, while the highest capacity is obtained from the biosystem is $1.6525 \times 10^{-4} \mathrm{mg} / \mathrm{g}$ for 114 hours. The bacteria that act to decreased identified as Pseudomonas sp., Aeromonas $\mathrm{sp}$. and Plesiomonas sp, with Pseudomonas sp more dominant in the degrading of dye RBB. The value of the colonists before degradation of $7.2 \times 10^{4} \mathrm{CFU} / \mathrm{gr}$ and the value after the degradation of $2.6 \times 10^{3} \mathrm{CFU} / \mathrm{gr}$.
\end{abstract}

Keywords: Biodegradation ; Remazol Brilliant Blue ; Inoculum ; Bacteria ; Biosystem.

\section{PENDAHULUAN}

Limbah industri semakin bertambah, baik volume maupun jenisnya. Hal ini menyebabkan beban pencemaran lingkungan semakin berat, sedangkan kemampuan alam untuk menerima beban limbah terbatas. Jenis limbah industri banyak macamnya, tergantung bahan baku dan proses yang digunakan masing-masing industri. Setiap limbah memerlukan penanganan tersendiri agar dapat mencapai baku mutu yang ditetapkan oleh pemerintah sebelum masuk ke lingkungan (Sastrawidana et al., 2010). Salah satu limbah industri yang menjadi kontributor utama penyebab pencemaran air adalah limbah zat warna yang dihasilkan dari proses pencelupan pada suatu industri tekstil, seperti zat warna $a z o$.

Zat warna $a z o$ disintesis untuk tidak mudah rusak melalui perlakuan kimia maupun fotolitik. Oleh sebab itu, bila limbah tersebut dibuang ke perairan akan mengganggu estetika dan meracuni biota air di dalam badan air tersebut. Hal ini dikarenakan berkurangnya oksigen yang dihasilkan selama proses fotosintesis akibat terhalangnya sinar matahari untuk masuk ke dalam badan air yang disebabkan oleh keberadaan limbah zat warna. Selain itu perombakan zat warna azo secara aerobik pada dasar perairan menghasilkan senyawa amina aromatik yang kemungkinan lebih toksik dibandingkan dengan zat warna azo itu sendiri (Zee, 2002). Remazol brilliant blue sangat tahan terhadap oksidasi kimia karena kestabilan struktur aromatic antaquinon.

Metode alternatif yang dapat digunakan untuk menangani masalah di atas adalah penggunaan mikroorganisme untuk mengolah limbah tekstil yang disebut metode biodegradasi yang sangat berpotensi untuk dikembangkan karena limbah tekstil dengan kandungan bahan organik yang tinggi dapat dimanfaatkan secara langsung maupun tidak langsung oleh mikroorganisme sebagai nutrisi untuk pertumbuhannya.

Metode biodegradasi ini diterapkan untuk melenyapkan bahan pencemar yang terkontaminasi dalam perairan. Perangkat yang digunakan dapat berupa bioreaktor tunggal dengan menggunakan 
pipa plastik yang didalamnya telah dihidupkan inokulum bakteri spesifik zat warna azo remazol brilliant blue. Metodenya dilakukan dengan menambahkan bahan pencemar ke dalam suatu bioreaktor tunggal (biofiltrasi vertikal) yang telah berisi media cair untuk pertumbuhan mikroba. Kultur mikroba yang digunakan adalah kultur campur. Keunggulan dari proses pengolahan air limbah dengan biofiltrasi vertikal ini adalah pengolahannya sangat mudah, biaya operasi yang rendah, dibandingakan dengan proses lumpur aktif, lumpur yang dihasilkan relatif sedikit (Hefang et al. 2004).

Denpasar merupakan kota dengan aktivitas yang padat, baik itu lalu lintasnya, penduduknya, maupun industrinya. Dalam bidang industri, aktivitas industri pencelupan terbilang cukup banyak dan menghasilkan limbah yang dibuang langsung ke sungai tanpa ditreatment terlebih daluhu. Sehingga menimbulkan pencemaran sungai. Salah satu sungai dengan limbah industri pencelupan dan percetakan adalah sungai Mati yang berada di Jalan Imam Bonjol, hal tersebut terbukti dari warna air sungai yang selalu berubah-ubah setiap minggunya dan menimbulkan bau yang tidak sedap dan jauh dari nilai estetika yang baik. Maka dari itu, sungai Mati memberikan kontribusi besar dalam pertumbuhan mikroorganisme zat warna tekstil yang mengandung zat warna sintetik khususnya remazol brilliant blue, dimana selain itu Sungai Mati banyak mengandung sampah, baik itu sampah organik maupun anorganik. Sampah-sampah tersebut mengandung limbah organik dan anorganik.

Berdasarkan permasalahan di atas, penelitian ini ditujukan untuk memperoleh suspensi aktif terbaik yang ditumbuhkan dari sampel sedimen tanah Sungai Mati Jalan Imam Bonjol Denpasar sebagai sumber inokulum bakteri yang mampu mendegradasi zat warna remazol brilliant blue dan menentukan besarnya efektivitas dan kapasitas biosistem yang diinokulasi suspensi aktif dalam mendegradasi zat warna remazol brilliant blue.

\section{METODOLOGI}

\subsection{Bahan}

Bahan yang digunakan yaitu sedimen yang berasal dari Sungai Mati Imam Bonjol,Denpasar, glukosa $; \mathrm{K}_{2} \mathrm{HPO}_{4} ; \mathrm{KH}_{2} \mathrm{PO}_{4} ;\left(\mathrm{NH}_{4}\right)_{2}\left[\mathrm{Fe}\left(\mathrm{SO}_{4}\right)_{2}\right] .6 \mathrm{H}_{2} \mathrm{O}$; $\mathrm{MgSO}_{4} ; \mathrm{FeSO}_{4}$; ekstrak ragi, remazol brilliant blue, batu vulkanik steril, NPK dan aquades.

\subsection{Peralatan}

Alat yang digunakan dalam penelitian ini adalah gelas ukur, gelas beker, sendok plastik, kantong plastik, ice box, paralon, erlenmeyer, batang pengaduk, aluminium foil, kertas saring, pipet volume, labu ukur, pipet tetes, selang aerator, aerator, kapas, furnace, desikator, oven, timbangan analitik, saringan plastik, kawat, tabung biofiltrasi vertikal dengan diameter $12 \mathrm{~cm}$ dan tinggi $60 \mathrm{~cm}$ dan Spektrofotometer UV-Vis Shimidzu 1800.

\subsection{Cara Kerja}

\section{A. Pengambilan Sampel}

Pengambilan sampel dari sedimen perairan pada beberapa titik di sungai Mati Jalan Imam Bonjol Denpasar diambil pada kedalaman $\pm 10-15 \mathrm{~cm}$ dari permukaan sedimen dengan berat 100 gram dengan menggunakan sendok plastik. Selanjutnya sampel yang telah didapat dimasukkan ke dalam kantong plastik lalu diberi label dan dimasukkan ke dalam kotak es (ice box). Sampel yang telah didapat diseeding di laboraorium Kimia FMIPA Universitas Udayana.

\section{B. Pembuatan media cair (Nutrien)}

Komposisi media cair yang digunakan adalah sebanyak 2,0 gram glukosa $(\mathrm{KH}) ; 0,1$ gram $\mathrm{K}_{2} \mathrm{HPO}_{4}$ ; 0,1 gram $\mathrm{KH}_{2} \mathrm{PO}_{4} ; 0,1$ gram $\left(\mathrm{NH}_{4}\right)_{2}\left[\mathrm{Fe}\left(\mathrm{SO}_{4}\right)_{2}\right] \cdot 6 \mathrm{H}_{2} \mathrm{O}$ ; 0,02 gram $\mathrm{MgSO}_{4} ; 0,02$ gram $\mathrm{FeSO}_{4} ; 0,02$ gram ekstrak ragi dan $2 \mathrm{mg}$ remazol brilliant blue kemudian dilarutkan dengan aquades. Selanjutnya campuran diaduk hingga homogen dan dimasukkan kedalam labu ukur $2 \mathrm{~L}$ dan diencerkan dengan aquades hingga tanda batas. Kemudian larutan media cair dimasukkan ke dalam erlenmeyer $2 \mathrm{~L}$, lalu Erlenmeyer ditutup dengan kapas dilapisi aluminium voil. Media disterilisasi selama 15 menit dengan suhu $121^{\circ} \mathrm{C}$ lalu didiamkan pada suhu $37^{\circ} \mathrm{C}$ selama 5 menit, selanjutnya media dapat disimpan dalam lemari pendingin sampai saat diperlukan (Ginting, 2007).

\section{Pembuatan Larutan Standar Remazol Brilliant Blue dan Larutan Limbah Remazol Brilliant Blue}

Larutan induk Remazol Brilliant Blue 1000 ppm, dibuat dengan menimbang 1 gram Remazol Brilliant Blue, dimasukkan kedalam labu takar 1000 $\mathrm{mL}$ kemudian dilarutkan dengan aquades hingga tanda batas. Untuk memperoleh larutan 20, 40, 80, 120, 160 dan 200 ppm, berturut - turut dipipet sebanyak 2, 4, 8, 12, 16 dan 20 mL larutan Remazol Brilliant Blue 1000 ppm lalu dimasukkan ke dalam labu takar $100 \mathrm{~mL}$ kemudian ditambahkan akuades hingga tanda batas. Larutan kemudian diukur dengan Spektrofotometer UV-Vis untuk menentukan panjang gelombang maksimum Remazol Brilliant Blue. Sedangkan untuk memperoleh air limbah artificial Remazol Brilliant Blue 200 ppm, dipipet 20 $\mathrm{mL}$ larutan Remazol Brilliant Blue 1000 ppm lalu dimasukkan ke dalam labu takar $100 \mathrm{~mL}$ kemudian ditambahkan akuades hingga tanda batas. 
D. Memperoleh Suspensi aktif Terbaik yang Ditumbuhkan dari Sampel Sedimen Tanah Aliran Sungai Jalan Imam Bonjol Denpasar sebagai Sumber Inokulum Bakteri dengan Waktu Tercepat dan VSS Terbesar

Dalam pembibitan dilakukan dengan menyiapkan 3 buah erlenmeyer $500 \mathrm{~mL}$ dengan kondisi bersih. Masing-masing sebanyak $250 \mathrm{~mL}$ media cair dimasukkan ke dalam erlenmeyer A, B dan $\mathrm{C}$ yang telah diisi label. Kemudian sampel sedimen dari beberapa titik di Aliran Sungai Mati di Jalan Imam Bonjol, Denpasar dimasukkan ke dalam erlenmeyer berbeda dengan massa 5 gram untuk masing - masing sampel. Setelah itu, media diaerasi dengan menggunakan aerator yang diberi selang, yang diletakkan di dasar erlenmeyer. Erlenmeyer ditutup dengan kapas kemudian diaerasi dan diinkubasi selama 3 hari. Kemudian pertumbuhan mikroba diamati dengan mengukur nilai VSS-nya dengan rentang waktu setiap 1 hari. Bibit yang paling cepat tumbuh dan memiliki nilai VSS tertinggi, maka sedimen tersebut merupakan bibit sedimen terbaik yang akan digunakan dalam pengolahan limbah (Suyasa, 2015).

\section{E. Menentukan Kapasitas dan Efektivitas Biosistem yang Diinokulasi Suspensi aktif dalam Mendegradasi Remazol Brilliant Blue}

Disiapkan pipa plastik berdiameter $12 \mathrm{~cm}$ dan tinggi $60 \mathrm{~cm}$ dengan dilengkapi kran di bagian bawah. Amobilisasi inokulum bakteri mengikuti metode yang telah dilakukan Castila, et al. (2003) yaitu, sebanyak 800 - $1000 \mathrm{~g}$ batu vulkanik steril dimasukkan ke dalam biosistem kemudian ke dalam tabung dimasukkan bibit yang menghasilkan bibit terbaik yang telah dilakukan pada percobaan 3.4.5 dengan cara mengambil bibit sedimen tersebut sebanyak 25,0 gram lalu ditambahkan media cair 1 $\mathrm{L}$ dan ditambahkan NPK hingga mencapai volume $2 \mathrm{~L}$, dimasukkan kedalam bioreaktor yang telah dimasukkan batu vulkanik. Larutan dimasukkan hingga batu vulkanik tersebut terendam semua. Bibit direndam dan sambil diamati terbentuknya filamen - filamen pada batu. Setelah perendaman selesai dilakukan selama 7 hari, ditentukan jumlah serta ciri koloni mikroba di Laboratorium Mikrobiologi. Pada bioreaktor yang berisi batu dimasukkan larutan remazol brilliant blue sebanyak $1000 \mathrm{~mL}$ dengan konsentrasi 200 ppm, kemudian setiap 6 jam kran pada bagian bawah tabung dibuka ditampung pada botol gelap $30 \mathrm{~mL}$. Larutan yang tertampung di botol gelap diukur penurunan konsentrasinya dengan menggunakan Spektrofotometer UV-Vis dengan panjang gelombang maksimumnya setiap 6 jam. Setelah itu ditentukan jumlah serta ciri koloni mikroba di Laboratorium Mikrobiologi, kemudian efektivitas dan kapasitas biositem.

\section{HASIL DAN PEMBAHASAN}

Berdasarkan hasil pengukuran, dapat diketahui panjang gelombang maksimum untuk larutan RBB adalah 591,0 nm. Selanjutnya panjang gelombang maksimum tersebut digunakan untuk pembuatan kurva kalibrasi.

\subsection{Suspensi aktif Terbaik sebagai Sumber Inokulum Bakteri dengan VSS (Volatil Suspended Solid) Terbesar}

Sampel bibit diamati pertumbuhan mikroba dengan mengukur nilai VSS setiap 6 jam selama empat hari waktu aerasi (proses penambahan oksigen) dengan perlakuan yang sama untuk masingmasing sedimen. Aerasi berfungsi untuk mensuplai jumlah oksigen terlarut dalam media sehingga cukup untuk tumbuh kembang dari mikroorganisme (Suharto, 2010). Peningkatan nilai VSS dapat dilihat pada kurva Gambar 1.

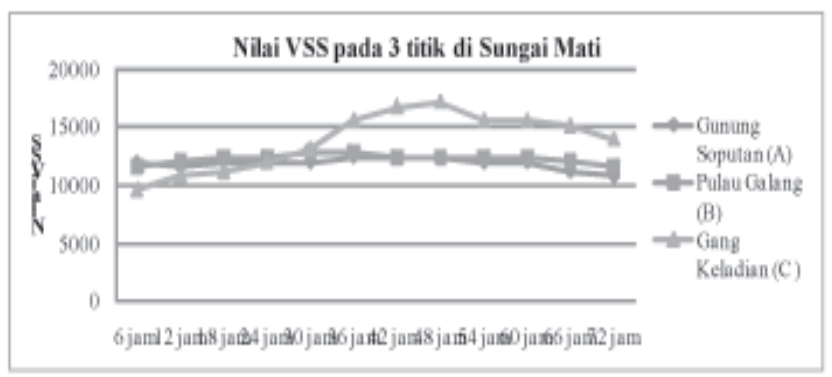

Gambar 1. Kurva Nilai VSS rata-rata pada Tiga Titik Sungai Mati Selama Pembibitan.

Berdasarkan kurva diatas selama 72 jam terlihat peningkatan nilai VSS selama pembibitan yang menyatakan adanya peningkatan biomassa. Aktivitas mikroorganisme ditandai dengan adanya pembelahan sel sehingga terbentuk sel baru pada sistem suspensi aktif (Soeparno, 1992). Semakin tinggi aktivitas mikroorganisme dalam menguraikan bahan organik maka semakin tinggi pula biomassa yang dihasilkan. Peningkatan biomassa ini menyatakan jumlah bahan organik yang telah didegradasi oleh mikororganisme (Atlas and Bartha, 1987). Bibit sedimen Gang Keladian Imam Bonjol memberikan nilai VSS tertinggi yaitu $17200 \mathrm{mg} / \mathrm{L}$ selama pembibitan 48 jam, dibandingkan dengan bibit sedimen Pertigaan Jalan Gunung Soputan yaitu $12400 \mathrm{mg} / \mathrm{L}$ dan bibit sedimen Pertigaan Jalan Pulau Galang yaitu $12400 \mathrm{mg} / \mathrm{L}$. Nilai VSS pada bibit sedimen Titik A dan bibit sedimen Titik B rendah dibandingkan bibit sedimen Titik $\mathrm{C}$ dikarenakan pertumbuhan mikroorganisme pada bibit tersebut lambat yang disebabkan oleh waktu adaptasi yang lebih lama pada media selektif. Nutrien merupakan salah satu faktor yang sangat mempengaruhi pertumbuhan sel serta aktivitas enzim yang dihasilkan oleh mikroorganisme dalam mendegradasi 
bahan pencemar. Jumlah mikroorganisme yang dapat tumbuh pada proses pembibitan dipengaruhi oleh faktor aerasi dan nutrien. Pemberian aerasi dan nutrien yang seimbang akan memenuhi kebutuhan mikroorganisme sebagai makanannya sehingga dapat meningkatkan pertumbuhan yang akan berbanding lurus dengan jumlah bahan pencemar yang akan terdegradasi (Sudaryati et al., 2011). Sehingga suspensi aktif yang berasal dari bibit sedimen Sungai Mati di Gang Keladian Jalan Imam Bonjol, Denpasar sangat baik digunakan pada biosistem yang diinokulasi suspensi aktif untuk mengolah limbah zat warna RBB.

\subsection{Perubahan Kadar Limbah Remazol} Brilliant Blue selama Perlakuan dalam Biosistem yang Diinokulasi Suspensi aktif. Penentuan konsentrasi limbah RBB dalam sistem biofiltrasi dilakukan dengan lumpur aktif (suspensi aktif) yang telah diamobilisasi dengan batu vulkanik untuk mengolah air limbah artificial dengan kadar RBB 200 mg/L. Sedimen tanah yang menghasilkan nilai VSS terbesar digunakan untuk mengolah limbah RBB dalam biofiltrasi yang terbuat dari pipa paralon berdiameter $12 \mathrm{~cm}$ dengan tinggi $60 \mathrm{~cm}$. Berikut merupakan hasil konsentrasi limbah RBB dalam biofiltrasi yang ditambahkan suspensi aktif pada pada Gambar 2 berikut.

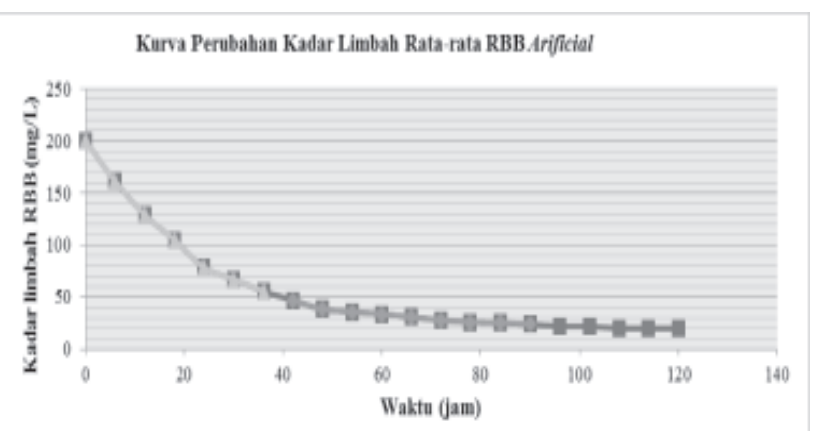

Gambar 2. Kurva Kadar Rata-rata Limbah RBB Artificial dari jam ke-0 hingga jam ke-120.

Berdasarkan hasil pengolahan menggunakan biosistem dengan inokulum bakteri yang diamobiloisasi pada batu vulkanik diketahui terjadi penurunan konsentrasi air limbah RBB artificial dalam 6 jam pertama diketahui penurunan konsentrasinya menjadi $160.7842 \mathrm{mg} / \mathrm{L}$ dari konsentrasi awal $200 \mathrm{mg} / \mathrm{L}$. Penurunan terus terjadi hingga mencapai waktu ke 114 jam dengan konsentrasi air limbah RBB artificial menjadi $19.6211 \mathrm{mg} / \mathrm{L}$. Kemudian terjadi peningkatan konsentrasi air limbah RBB artificial menjadi $19.8209 \mathrm{mg} / \mathrm{L}$ pada waktu ke 120 jam. Mikroorganisme dengan bantuan kosubstrat seperti glukosa berfungsi sebagai donor elektron ke zat warna azo yang dikatalisis oleh enzim azoreductase sehingga terjadi pemutusan ikatan azo menghasilkan amina aromatik. Penurunan konsentrasi yang besar menandakan bakteri mampu mendegradasi zat warna RBB dari awal konsentrasi $200 \mathrm{mg} / \mathrm{L}$ menjadi $19.6211 \mathrm{mg} / \mathrm{L}$. Proses perombakan zat warna $a z o$, khususnya RBB oleh bakteri yang terlekat pada media batu pada dasarnya merupakan suatu reaksi redoks yang dikatalisis oleh enzim. Pada proses glikolisis glukosa koenzim nikotinamida adenine dinukleotida $\left(\mathrm{NAD}^{+}\right)$dibebaskan dengan bantuan enzim dehirogenase yang berperan sebagai pembawa elektron dan terlibat dalam reaksi enzimatik. Pada kondisi tidak ada oksigen, NADH mengalami reaksi oksidasi mengasilkan $\mathrm{NAD}^{+}$sedangkan zat warna $a z o$ mengalami reaksi reduksi menghasilkan aminaamina aromatik yang bersesuaian. Putusnya ikatan azo pada zat warna azo menyebabkan warna menjadi hilang. Namun jika terdapat oksigen, maka zat warna azo dan oksigen berkompetisi sebagai penerima elektron dari NADH. Ion hidrogen pada NADH lebih mudah ditransfer ke oksigen melalui rantai transfer elektron. Dengan demikian, pada kondisi aerobik zat warna azo sulit direduksi sehingga warnanya tetap. Berikut merupakan perombakan zat warna azo dengan adanya kosubstrat yang dilaporkan oleh Van der Zee (2002) yang disajikan pada Gambar 3

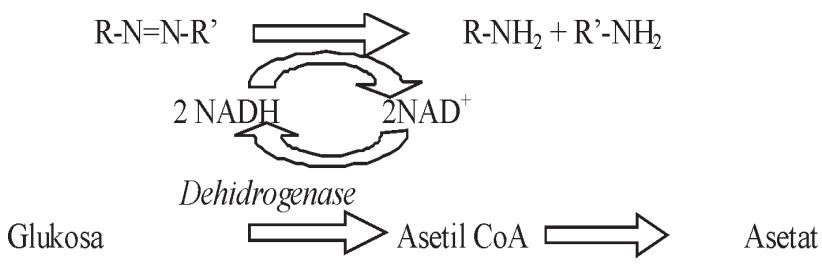

Gambar 3. Mekanisme perombakan zat warna azo secara direct enzymatic.

\subsection{Laju Penurunan Kadar Limbah RBB Arti- ficial selama Perlakuan dalam Biosistem yang Diinokulasi Suspensi aktif.}

Laju penurunan kadar limbah RBB artificial dapat ditentukan dengan manerapkan data penurunan kadar limbah RBB yang diperoleh dalam persamaan $\mathrm{y}=0.00834 \mathrm{x}+0.03516$, dimana y adalah serapan dari sampel dan $\mathrm{x}$ adalah kadar dari limbah. Laju penurunan tersebut dibagi menjadi tiga laju penurunan. Pertama laju penurunan cepat, kedua laju penurunan lambat dan yang ketiga adalah laju penurunan stagnan (tetap). Dimana laju penurunan cepat digambarkan pada Gambar 4.

Dari Gambar 4 terjadi proses penurunan konsentrasi limbah RBB artificial yang cepat dari jam ke-0 hingga jam ke-36. Dimana terjadi penurunan yang berlangsung cepat dengan persamaan $\mathrm{y}==-4.001 \mathrm{x}+185.4$ dengan koefisien regresi linier $\left(\mathrm{R}^{2}\right)$ sebesar 0.958. Nilai slope yang merupakan tetapan laju penurunan konsentrasi 


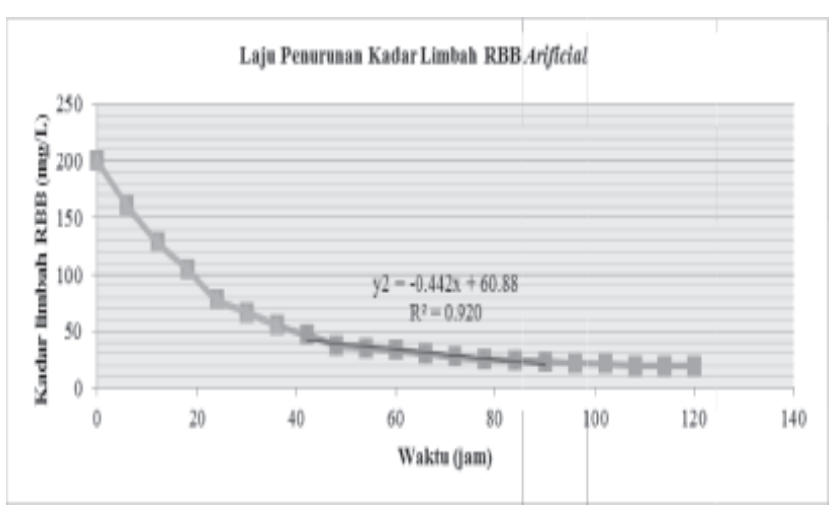

Gambar 4 Kurva Laju Penurunan Kadar Limbah RBB Artificial dari jam ke-0 hingga jam ke-120.

Keterangan : $y_{1}=$ persamaan garis laju penurunan cepat

$y_{2}=$ persamaan garis laju penurunan lambat

$\mathrm{y}_{3}=$ persamaan garis laju penurunan stagnan

limbah RBB artificial (k) adalah -4.001, dari nilai tersebut dapat dinyatakan bahwa laju penurunan konsentrasi limbah RBB artificial dari jam ke-0 hingga jam ke-36 adalah sebesar $4.001 \mathrm{mg} / \mathrm{L} / \mathrm{jam}$. Selanjutnya pada jam ke 42 hingga jam 90 jam terjadi laju penurunan lambat dengan persamaan $\mathrm{y}=$. $0.442 x+60.88$ dengan koefisien regresi linier $\left(R^{2}\right)$ sebesar 0.920. Nilai slope yang merupakan tetapan laju penurunan konsentrasi limbah RBB artificial (k) adalah -0.442, dari nilai tersebut dapat dinyatakan bahwa laju penurunan konsentrasi limbah RBB artificial dari jam ke-42 hingga jam ke-78 adalah sebesar $0.442 \mathrm{mg} / \mathrm{L} / \mathrm{jam}$. Laju penurunan terakhir proses penurunan konsentrasi limbah RBB artificial yang sangat lambat atau bisa dikatakan stagnan dari jam ke-96 hingga jam ke-120. Dimana terjadi penurunan yang berlangsung sangat lambat dengan persamaan $\mathrm{y}=-0.099 \mathrm{x}+31.26$ dengan koefisien regresi linier $\left(R^{2}\right)$ sebesar 0.791. Nilai slope yang merupakan tetapan laju penurunan konsentrasi limbah RBB artificial (k) adalah -0.099 dari nilai tersebut dapat dinyatakan bahwa laju penurunan konsentrasi limbah RBB artificial dari jam ke-96 hingga jam ke-120 adalah sebesar $0.099 \mathrm{mg} / \mathrm{L} / \mathrm{jam}$. Laju penurunan konsentrasi limbah RBB artificial yang berlangsung cepat ini menunjukkan bahwa proses biodegradasi limbah RBB mampu menguraikan dengan cepat zat warna RBB. Hal ini menandakan bahwa mikroorganisme yang terdapat pada sedimen hasil pembibitan mampu untuk menurunkan konsentrasi limbah RBB artificial dengan baik. Penurunan ini juga dikarenakan mikroorganisme di dalam biosistem mengalami fase eksponensial dengan kandungan nutrien yang berlimpah dan mikroorganisme melakukan mekanisme pertahanan diri agar tetap hidup (Gadd, 1990). Sedangkan laju penurunan lambat ini menunjukkan bahwa proses biodegradasi limbah
RBB melambat dalam menguraikan zat warna RBB. Hal ini dikarenakan mikroorganisme mengalami penurunan dalam melakukan mekanisme untuk menurunkan konsentrasi limbah RBB. Selain juga dikarenakan nutrien yang tersedia mulai berkurang dengan jumlah mikroorganisme yang semakin banyak. Semakin memperbesar persaingan antar mikroorganisme untuk mendapatkan nutrien, sehingga kemampuan mikroorganisme untuk menurunkan konsentrasi limbah RBB semakin menurun. Sebab nutrien merupakan salah satu faktor yang sangat mempengaruhi pertumbuhan sel serta aktivitas enzim yang dihasilkan oleh mikroorganisme untuk menurunkan konsentrasi limbah RBB dalam larutan (Soeparno, 1992). Hal ini dikarenakan mikroorganisme mengalami penurunan dalam melakukan mekanisme untuk menurunkan konsentrasi limbah RBB. Ini merupakan fase stasioner, dimana kecepatan pertumbuhan seimbang dengan kematian sel, tidak ada peningkatan sel, metabolisme menurun. Selain itu juga dikarenakan nutrien yang tersedia telah habis dengan jumlah mikroorganisme yang semakin banyak, sehingga kemampuan mikroorganisme untuk menurunkan konsentrasi limbah RBB menurun dan akhirnya stagnan.

\subsection{Efektivitas Biosistem yang Diinokulasi Suspensi aktif dalam Mendegradasi Remazol Brilliant Blue.}

Efektivitas biosistem dalam presentase ditentukan dengan membandingkan konsentrasi tertinggi dari hasil penurunan konsentrasi limbah RBB artificial dengan penurunan konsentrasi limbah RBB artificial hingga waktu akhir penurunan. Efektivitas biosistem suspensi aktif dalam mengolah limbah RBB artificial terbesar pada saat waktu pengolahan sampel ke 114 jam, yaitu sebesar 90.19 $\%$. Hal ini menunjukkan bahwa pada waktu pengolahan ke 114 jam mikroorganisme dalam biosistem telah dapat bekerja optimum untuk mengolah limbah RBB artificial. Efisiensi menurun setelah waktu pengolahan $114 \mathrm{jam}$, yang ditunjukkan pada waktu pengolahan 120 jam dengan nilai efektivitas sebesar $90.09 \%$. Penurunan efisiensi terjadi karena meningkatnya toksisitas zat warna terhadap bakteri yang merupakan racun bagi bakteri dan terbloknya sisi aktif dari enzim azo reductase oleh molekul zat warna. Selain itu mulai pada jam ke 42 selisih efektivitas setiap jam penurunan semakin berkurang. Hal itu terjadi karena kemampuan bakteri dalam menguraikan limbah zat warna RBB artificial semakin berkurang, namun tetap meningkatkan efektivitas setiap jamnya hingga mencapai $90.19 \%$ pada jam ke-114. 
Tabel 2 Hasil Identifikasi Bakteri dalam Biosistem

\begin{tabular}{ccccccc}
\hline $\begin{array}{c}\text { Kode } \\
\text { Sampel }\end{array}$ & $\begin{array}{c}\text { Coliform } \\
\text { (MPN/100gr) }\end{array}$ & $\begin{array}{c}\text { E.coli } \\
\text { (MPN/100 gr) }\end{array}$ & $\begin{array}{c}\text { Pseudomonas sp. } \\
\text { (CFU/gr) }\end{array}$ & $\begin{array}{c}\text { Aeromonas sp. } \\
\text { (CFU/gr) }\end{array}$ & $\begin{array}{c}\text { Vibrio sp. } \\
\text { (CFU/gr) }\end{array}$ & $\begin{array}{c}\text { Plesiomonas sp. } \\
\text { (CFU/gr) }\end{array}$ \\
\hline A & 95 & 95 & $7.2 \times 10^{4}$ & $6.3 \times 10^{3}$ & 0 & $1.4 \times 10^{3}$ \\
B & 70 & 70 & $2.6 \times 10^{3}$ & $2.0 \times 10^{2}$ & 0 & $8.0 \times 10^{2}$ \\
\hline
\end{tabular}

Sumber : Laboratorium Mikrobiologi Jurusan Biologi FMIPA UNUD

Keterangan: A: Sampel filamen sebelum biosistem diberikan limbah

B : Sampel filamen setelah biosistem diberikan limbah

\subsection{Kapasitas Biosistem yang Diinokulasi Suspensi aktif dalam Mendegradasi Remazol Brilliant Blue.}

Kapasitas merupakan kemampuan daya serap atau daya tampung yang dilakukan oleh biosistem yang diinokulasi Suspensi aktif dalam mendegradasi limbah RBB artificial. Dimana telah diketahui konsentrasi penurunan limbah RBB artificial, sehingga bisa ditentukan nilai kapasitas dari biosistem tersebut. Kapasitas terbesar dari biosistem suspensi aktif dalam menurunkan konsentrasi limbah RBB artificial adalah sebesar $1.6925 \mathrm{x} \mathrm{mg/}$ gram. Hal ini menunjukkan bahwa kemampuan terbaik dari biosistem ditunjukkan pada pengolahan limbah selama 114 jam. Dimana kemampuan biosistem untuk menurunkan konsentrasi limbah RBB cukup berhasil dengan nilai kapasitas sebesar $1.6925 \mathrm{x} \mathrm{mg} / \mathrm{gram}$, yang berarti kemampuan per gram berat batu vulkanik dapat menurunkan konsentrasi limbah RBB sebesar 1.6925 miligram.

\subsection{Identifikasi Mikroorganisme yang Berperan dalam Penurunan Konsentrasi Limbah RBB pada Biosistem yang diinokulasi suspensi aktif}

Dari hasil uji identifikasi didapatkan hasil jumlah masing-masing bakteri dan jumlah total mikroorganisme, seperti pada tabel 2.

Berdasarkan Tabel 2 diketahui bahwa bakteri yang terdapat pada biosistem adalah Coliform, E.coli, Pseudomonas sp, Aeromonas sp., dan Plesiomonas sp., sedangkan Vibrio sp. tidak terdapat dalam biosistem. Dimana bakteri-bakteri tersebut mampu mendegradasi limbah zat warna RBB yang ditunjukkan oleh hasil dari jumlah koloni dari setiap bakteri tersebut. Bakteri yang memberikan jumlah koloni tertinggi tertinggi adalah bakteri Pseudomonas sp. yang menunjukkan nilai sebelum degradasi sebesar $7.2 \times 10^{4} \mathrm{CFU} / g r$ dan nilai sesudah degradasi sebesar $2.6 \times 10^{3} \mathrm{CFU} / g r$. Kedua adalah bakteri Aeromonas sp. yang menunjukkan nilai sebelum degradasi sebesar 6.3 x CFU/gr dan nilai sesudah degradasi sebesar $2.0 \times \mathrm{CFU} / \mathrm{gr}$. Ketiga adalah bakteri Plesiomonas sp. yang menunjukkan nilai sebelum degradasi sebesar 1.4 x CFU/gr dan nilai sesudah degradasi sebesar 8.0 x CFU/gr. Hal ini menunjukkan bahwa bakteri Pseudomonas sp., Aeromonas sp. dan Plesiomonas sp. mampu menguraikan dan tahan terhadap paparan zat warna remazol brilliant blue.

\section{SIMPULAN DAN SARAN}

\subsection{Simpulan}

Berdasarkan hasil penelitian dan pembahasan maka dapat ditarik simpulan sebagai berikut:

1. Suspensi aktif terbaik diperoleh dari pembibitan sampel tanah dari sedimen Sungai Mati Jalan Imam Bonjol Denpasar dengan nilai Volatil Suspended Solid (VSS) dari pertumbuhan biomassa mikroorganisme terbanyak sebesar $17200 \mathrm{mg} / \mathrm{L}$ dalam 48 jam.

2. Efektivitas yang diperoleh dari biosistem yang diinokulasi suspensi aktif dalam mendegradasi zat warna remazol brilliant blue adalah sebesar 90.19\% selama 114 jam, sedangkan kapasitas terbesar yang diperoleh dari biosistem yang diinokulasi suspensi aktif dalam mendegradasi zat warna remazol brilliant blue adalah 1.6525 $\mathrm{x} \mathrm{mg} / \mathrm{gram}$ selama 114 jam.

3. Bakteri yang dapat menguraikan zat warna remazol brilliant blue adalah Pseudomonas sp., Aeromonas sp. dan Plesiomonas sp, dengan bakteri Pseudomonas sp. yang lebih dominan dalam mendegradasi zat warna RBB yang menghasilkan jumlah koloni awal sebelum degradasi $7.2 \times \mathrm{CFU} / \mathrm{gr}$ dan nilai sesudah degradasi sebesar 2.6 x CFU/gr.

\subsection{Saran}

Dari penelitian yang telah dilakukan terdapat beberapa hal yang menarik untuk diperhatikan lebih lanjut, antara lain :

1. Perlu dilakukan penelitian lanjutan mengenai proses pengolahan limbah zat warna tekstil dengan sistem kombinasi anaerobik-aerobik.

2. Perlu dilakukan penelitian dengan menggunakan parameter lain seperti Total Suspended Solid (TSS), COD dan BOD dengan waktu pengolahan yang lebih lama untuk melihat kemampuan bibit inokulum dan efektivitasnya. 
3. Perlu dilakukan pemurnian bakteri Pseudomonas sp. dan Aeromonas sp. untuk mengetahui hasil lebih lanjut.

\section{DAFTAR PUSTAKA}

Atlas, R. M and R. Bartha, 1987, Microbial Ecology : Fundmentals and Applications $2^{\text {nd }}$ ed, Menlo Park : The Benjamin / Cummings Publ, Co., Inc.

Bollag, W. B and Bollag, J. M, 1992, Biodegradation Encyclopedia of Microbiology, Ledergerg, J, Ed, Academic Press Inc, Boston : 269 - 276.

Dad, 2000, Bacterial Chemistry and Physiology, John Wiley and Sons Inc., NewYork.

Fessenden,R.J. dan J.S. Fessenden. 1999. Kimia Organik. Jilid 1, a.b. Aloysius Hadyana Pudjaatmaka, Erlangga, Jakarta.

Gadd, G. M., 1990, Metal Tolerance in Microbiology of Extreme Envirenment, Edward, C., ed, Open University Press, Milton Keynes : 178-210.

Ginting, P, 2007, Sistem Pengelolaan Lingkungan dan Limbah Industri, Yrama Widya, Bandung.

Hefang, HuWenrong and LiYuezhong, 2004, Biodegradition mechanisms and kinetics of $a z o$ dys 4BS by a micobial consortium, Chemosphere 57:293-301.

Indrawati, 2008, Dekolorisasi Larutan Remazol Brilliant Blue Menggunakan Ozon Hasil
Elektrolisis, Makalah Penelitian UNDIP, Semarang.

Manurung, R \& Irvan, 2004, Perombakan Zat Warna Azo Reaktif Secara Anaerob, Jurnal Kimia USU, Sumatera Utara.

Metcalf And Eddy, 2003, Wastewater Engineering, Treatment and Reuse. Fourth Edition, McGraw Hill Higher Education, New York.

Sastrawidana, I Dewa K., Bibiana W. Lay, Anas Miftah Fauzi, Dwi Andreas Santoso, 2010, Pengolahan Limbah Tekstil Sistem Kombinasi Anaerobik-aerobik Menggunakan Biofilm Bakteri Konsorsium dari Lumpur Limbah Tekstil, Ecotrophic 3 (2) :55-60.

Soeparno, 1992, Ilmu dan Teknologi Daging, Gajah Mada University, Yogyakarta.

Sudaryati, YS., Rahayu, SH., Setianingrum, N., Naiola, E, 2011, Kemampuan Bacillus licheniformis dalam Memproduksi Enzim Protease yang Bersifat Alkalin dan Termofilik, Artikel, Media Litbang Kesehatan Volume 21 Nomor 2 Tahun 2011.

Suyasa, Wayan Budiarsa, 2015, Pencemaran Air dan Pengolahan Air Limbah, Udayana University Press, Denpasar.

Van der Zee, 2002, Anaerobic azo dye reduction, Thesis, Wageningen University, Netherland. 